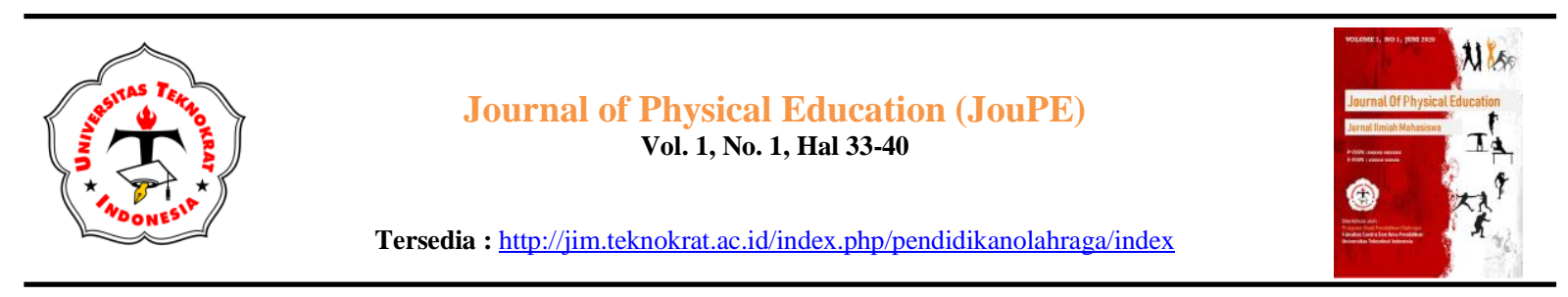

\title{
PENINGKATAN KETERAMPILAN GERAK DASAR ROLL BELAKANG PADA ANAK SEKOLAH DASAR
}

\author{
Farhan Ramadhani Pangkey ${ }^{1}$, Imam Mahfud ${ }^{2}$ \\ Universitas Teknokrat Indonesia ${ }^{1,2}$ \\ farhanramadhanipangkey04@gmail.com ${ }^{1}$ \\ imam_mahfud@teknokrat.ac.id ${ }^{2}$
}

\begin{abstract}
The purpose of this research is to learn how to develop the back scrolls using helping tools in class III of Elementary School N 1 Beringin Raya, Bandarlampung in 2019. The method used in this study is a class-action study (class action study) with two cycles, from which each cycle uses different actions. The first cycle using subsection learning, and the second cycle with using teacher help. The study subject is class III, Elementary School N 1 Beringin Raya students who argue with 17 students. The data gathering taken through the tests consists of training basic rolls that load preliminary judgments, implementation and final judgments. The results of this study indicate improvement in skills roll the back of the base through the use of helping tools on each cycle, as for the improvement on each cycle, is as follows the first cycle of $52.94 \%$ and the second cycle of $82.35 \%$.
\end{abstract}

Keywords: Enhancement, Skills, Basic Movement, Gymnastics, Back Roll

\begin{abstract}
Abstrak
Tujuan dari penelitian ini adalah untuk mengetahui peningkatan keterampilan gerak dasar roll belakang dengan menggunakan alat bantu pada siswa kelas III SD N di Kota Kota Bandar Lampung. Metode yang digunakan pada penelitian ini adalah Penelitian Tindakan Kelas (Classroom Action Research) dengan dua siklus, dimana dari setiap siklusnya menggunakan tindakan yang berbeda-beda. Siklus yang pertama dengan penggunaan pembelajaran perbagian, dan siklus yang kedua dengan penggunaan bantuan guru. Subjek penelitian ini adalah siswa Kelas III Sekolah Dasar di Kota Bandar Lampung yang berjumlah 17 siswa. Pengumpulan data diambil melalui pengamatan keterampilan gerak dasar roll belakang yang meliputi sikap awal, pelaksanaan dan sikap akhir. Hasil dari penelitian ini menunjukkan adanya peningkatan terhadap keterampilan gerak dasar roll belakang melalui penggunaan alat bantu pada setiap siklusnya, adapun peningkatan pada setiap siklus adalah sebagai berikut siklus pertama sebesar 52,94 \%, dan siklus kedua 82,35 $\%$.
\end{abstract}

Kata Kunci: Peningkatan, Keterampilan, Gerak Dasar, Senam Lamtai, Roll Belakang

\section{To cite this article:}

Ramadhani, Farhan dan Mahfud , Imam (2020). Peningkatan Keterampilan Gerak Dasar Roll Belakang Pada Anak Sekolah Dasar. Journal Of Physical Education, 1 (1), 33-40 


\section{PENDAHULUAN}

Pendidikan Jasmani merupakan mata pelajaran yang terdapat pada kurikulum pendidikan disekolah. Mata pelajaran Pendidikan Jasmani ini dilaksanakan sesuai dengan misi pendidikan melalui aktivitas jasmani dan pembiasaan perilaku hidup sehat siswa. Pendidikan jasmani membantu siswa dalam memahami gerak manusia dan bagaimana cara untuk melakukan gerak secara aman, efisien, dan efektif sehingga siswa dapat menghargai manfaat aktifitas jasmani yang dilakukan guna peningkatan kualitas hidup dan pembiasaan pola hidup sehat dalam kehidupan sehari-hari (Yuliandra dan Fahrizqi, 2019).

Tujuan yang ingin dicapai pada mata pelajaran ini adalah membantu peserta didik untuk dapat meningkatkan kesegaran jasmani dan menjaga kesehatan yang dilaksanakan dengan cara pengenalan dan penanaman sikap positif serta kemampuan gerak dasar melalui berbagai aktivitas jasmani. Struktur dalam pendidikan jasmani berkaitan erat dengan bagaimana proses siswa belajar untuk dapat mencapai tujuan pendidikan dengan menggunakan aktifitas fisik sebagai medianya. Dalam pelaksanaanya, aktifitas jasmani yang dilakukan dipakai sebagai wahana pengalaman belajar peserta didik. Melalui pengalaman inilah peserta didik tumbuh dan berkembang sesuai dengan capaian tujuan Pendidikan Nasional. Menurut Gumantan dan Mahfud (2018) kegiatan olagraga di sekolah yang diberikan oleh guru pendidikan jasmani akan membantu pertumbuhan dan perkembangan siswa. Pendidikan jasmani adalah proses ajar melalui aktifitas jasmani yang erat kaitannya dengan gerak manusia. Gerak bagi manusia sebagai aktifitas jasmani merupakan kebutuhan yang sangat penting guna merangsang pertumbuhan dan perkembangan motorik anak. Terdapat berbagai bentuk dan macam kegiatan pendidikan jasmani di sekolah untuk mencapai tujuan pendidikan jasmani salah satunya yaitu senam lantai.

Senam lantai merupakan salah satu bagian dari cabang olahraga senam. Gerakan yang dilakukan pada senam lantai ialah gerakan senam yang dilaksanakan di atas lantai dengan alas matras. Salah satu materi yang terdapat pada senam lantai adalah roll belakang (berguling ke belakang). Roll belakang (berguling ke belakang) merupakan gerakan badan dengan cara berguling ke arah belakang yang dilakukan dengan tiga tahapan. Tahapan tersebut antara lain ialah, awalan, pelaksanaan, dan dilanjutkan dengan akhiran gerakan.

Pada proses pembelajaran jasmani pada kelas III di salah satu Sekolah Dasar di Bandar Lampung, tingkat kesuksesan pembelajaran masih belum maksimal. Tingkat kesuksesan yang didapatkan adalah $60 \%$ dari total siswa pada kelas tersebut. kurangnya tingkat penguasaan keterampilan roll belakang siswa ini, dikarenakan banyak faktor yang mempengaruhinya antara lain, Kurangnya penggunaan alat bantu dalam proses pembelajaran roll belakang. Agar penelitian ini tidak meluas, maka penelitian ini dibatasi hanya pada "Peningkatan Keterampilan Gerak Dasar Roll Belakang". Sesuai dengan masalah penelitian, maka tujuan penelitian ini adalah: Meningkatkan penguasaan keterampilan gerak roll belakang melalui penggunaan alat bantu pada pembelajaran pendidikan jasmani pada siswa kelas III Sekolah Dasar di Kota Bandar Lampung.

\section{TELAAH PUSTAKA \\ Keterampilan Gerak Dasar}

Gerak dasar merupakan gerak yang perkembangannya sejalan dengan pertumbuhan seseorang. Keterampilan gerak dasar merupakan pola gerak yang menjadi dasar untuk ketangkasan yang lebih kompleks. Menurut Lutan (1998) membagi tiga gerakan dasar yang melekat pada individu yaitu, 1) lokomotor, (2) gerak non lokomotor, (3) manipulatif. Gerakan ini merupakan salah satu bentuk gerakan motorik yang harus dikuasai siswa melalui pendidikan jasmani.

Pembelajaran motorik akan menghasilkan perubahan gerakan yang relatif permanen. Seseorang yang ingin memiliki keterampilan yang baik terlebih dahulu harus mengembangkan unsur gerak, kemudian hal ini dapat dilakukan melalui proses belajar dan berlatih yang dilakukan melalui mata pelajaran pendidikan jasmani disekolah. Menurut Mahfud dan Fahrizqi (2020) gerakan motorik adalah dasar dan fondasi yang kuat dalam rangka mendukung kegiatan pembelajaran, bermain, sosialisasi, dan menjadi salah satu bentuk guna membangun kepercayaan diri siswa. Kemampuan motorik akan sangat berguna bagi siswa dan menjadi dasar yang baik untuk perkembangan kognitif anak. Perkembangan motorik anak adalah suatu proses kematangan yang erat hubungannya dengan aspek deferensial bentuk atau fungsi termasuk perubahan sosial dan emosional (Hurlock, 1998).

\section{Senam Lantai}

Senam lantai disebut merupakan bagian integral dari cabang olahraga senam, yang biasa dilakukan dan diperlombakan oleh anak-anak dan orang dewasa. Untuk dapat melakukan senam lantai diperlukan 
keterampilan gerak tinggi, kelentukan, koordinasi gerakan, keberanian, percaya diri, dan kekuatan, yang baik. Maka dari itu, untuk dapat melakukan gerakan senam lantai diperlukan proses latihan atau pembelajaran yang terencana dan sistimatis guna mencapai tujuan pendidikan. Selain untuk mencapai tujuan pendidikan, dengan kegiatan yang sistematis dan terencana ini akan menghasilkan atlet senam yang handal. Menurut Mahendra (2004) Senam merupakan aktifitas fisik yang dilakukan untuk membantu mengoptimalkan perkembangan anak. Aktifitas dalam senam dapat membentuk perkembangan pola gerak yang bersifat fundamental seperti, gerak lokomotor, nonlokomotor, dan gerak manipulatif (Mulyana, 2018).

Seman lantai adalah salah satu bagian dari senam artistik. Artistic Gymnastics adalah senam yang digabungkan aspek tumbling dan akrobatik untuk menghasilkan efek artistik dari gerakan yang dilakukan pada tiap alat atau nomor (Hidayat, 1996). Gerakan tubuh yang sudah direncanakan dan disusun secara sistematis adalah konsep dasar pada senam lantai. Hal ini, dilakukan dengan tujuan untuk memperbaiki sikap, bentuk badan, membina dan meningkatkan kesegaran jasmani, serta membentuk dan mengembangkan keterampilan serta kepribadian siswa sesuai dengan tujuan pendidikan Nasional.

\section{Roll Belakang}

Yang dimaksud dengan roll belakang atau berguling ke belakang ialah gerakan badan berguling ke arah belakang melalui bagian belakang badan mulai dari pinggul bagian belakang, pinggang, punggung, dan tengkuk. Menurut Muhajir (2006) guling belakang merupakan kerak mengguling kebelakang dengan posisi badan tetap membulat, yaitu kaki dilipat, lutut melekat didada, kepala menunduk hingga dagu menyentuh dada. Urutan guling belakang adalah; sikap awal berjongkok dengan membelakangi matras dan kedua kaki rapat, selanjutnya posisi paha menempel dengan perut dagu menempel ke dada dan kedua telapak tangan menghadap ke atas dengan ibu jari berada disamping telinga, berguling secara berurutan dari pinggul ke punggung dan pundak dengan posisi melengkung setengah lingkaran, kedua tangan menyentuh matras dengan menarik kaki yang berada diatas dijatuhkan ke belakang kepala, letakkan ujung kaki pada matras dengan tangan mendarat pada matras dan badan serta kepala terangkat, berjongkok dengan tumpun kedua lengan sebagai sikap akhir (Mulyaningsih, 2010).

\section{METODE}

Penelitian ini merupakan penelitian tindakan, karena penelitian ini dilakukan dengan metode kaji tindak dengan menggunakan pedoman penelitian tindak kelas (Classroom Action Research) CAR. Penelitian tindakan kelas merupakan suatu pencermatan terhadap kegiatan belajar berupa sebuah tindakan (Arikunto, 2010). Dari namanya sudah menunjukkan isi yang terkandung di dalamnya, yaitu sebuah kegiatan penelitian yang dilakukan di kelas atau di lapangan dikarenakan ada 3 kata yang membentuk pengertian tersebut, maka ada tiga pengertian yang dapat di terangkan, (1) Penelitian menunjukkan pada suatu kegiatan mencermati suatu objek dengan menggunakan cara dan aturan metodologi tertentu untuk memperoleh data atau informasi yang bermanfaat dalam meningkatkan mutu suatu yang menarik minat dan penting bagi peneliti, (2) Tindakan menujuk pada suatu gerak kegiatan yang sengaja dilakukukan dengan tujuan tertentu dalam penelitian pembentuk merangkaikan siklus kegiatan siswa, dan (3) Kelas dalam hal ini tidak terikat pada pengertian ruang kelas, tetapi ruang kelas dalam penelitain, yang lebih sepesifik seperti yang lama dikenal dalam bidang pendidikan dalam pengajaran yang dimaksud dengan istilah kelas adalah sekelompok siswa sekelas yang sama dari guru yang sama pula. Pada penelitian tidakan ini berciri sebagai berikut:

a. Praktis dan langsung relevan untuk situasi aktual.

b. Menyediakan kerangka kerja yang teratur untuk memecahkan masalah dan perkembangan-perkembangan yang lebih baik.

c. Dilakukan melalui putaran-putaran yang berspiral.

Penelitian tindakan kelas dilakukan melalui putaran atau spiral dengan beberapa siklus yang terdiri dari merencanakan, tahap melakukan tindakan, pengamatan (Observasi) dan tahap refleksi. Yang dimaksud dengan penelitian yang dilakukan melalaui putaran spiral adalah penelitian yang melalui siklus-siklus berikut ini: 


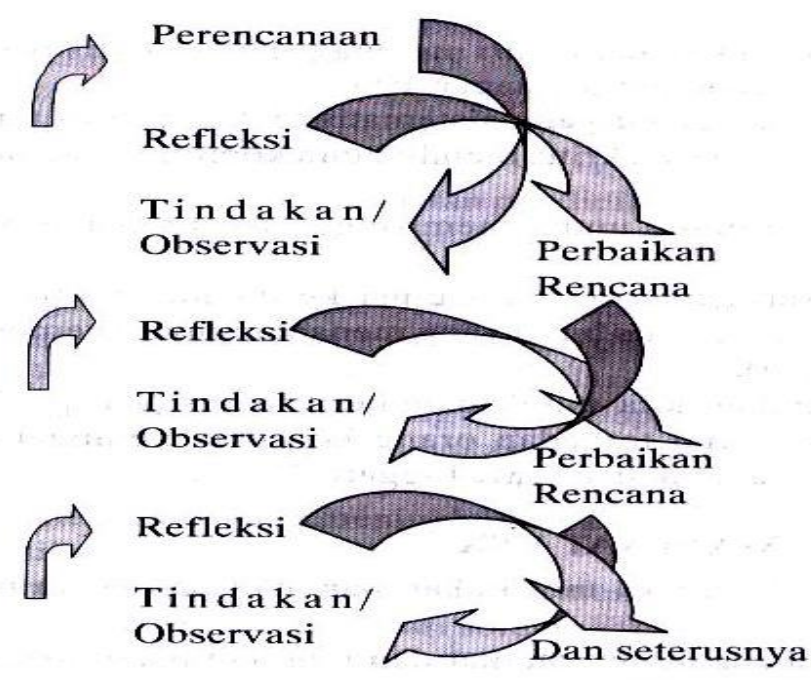

Gambar 1. Siklus Penelitian Tindakan Kelas

Perencanaan (Planning), dalam tahap ini peneliti menjelaskan tentang apa, mengapa, kapan, dimana,oleh siapa dan bagaimana tindakan tersebut dilakukan. Tindakan berupa pelaksanaan yang merupakan implementasi atau penerapan isi rancangan, yaitu mengenakan tindakan di kelas. Observasi adalah kegiatan pengamatan yang dilakukan oleh pengamat oleh suatu tindakan. Refleksi adalah merupakan kegiatan untuk mengemukakan kembali apa yang sudah dilakukan. Perbaikan rencana adalah memperbaiki suatu tindakan yang sudah dilaksanakan apabila tidak sesuai dengan tujuan yang diinginkan atau tindakan sesuai rencana.

\section{Teknik Analisis Data}

Setelah data dikumpulkan melalui tindakan disetiap siklusnya, selanjutnya data dianalisis melalui tabulasi, presentase dan normatif. Tenik penilaian dalam proses pembelajaran menggunakan penilaian kwantitatif untuk melihat kwalitas hasil tindakan disetiap siklus menggunakan rumus sebagai berikut:

Keterangan:

$$
P=\frac{f}{n} x 100 \%
$$

$\mathrm{P}$ : Presentase keberhasilan

$\mathrm{F}$ : Jumlah gerakan yang dilakukan dengan benar

$\mathrm{N}$ : Jumlah siswa yang mengikuti tes

\section{Proses Pembelajaran Keterampilan Gerak Dasar Roll Belakang}

\section{Siklus Pertama}

a. Rencana

1. Menyiapkan skenario pembelajaran yang berisi tentang kegiatan-kegiatan yang dilakukan meliputi kegiatan pendahuluan, inti, penutup.

2. Menyiapkan alat-alat berupa matras dan mengunakan papan yang berbentuk segitiga untuk membuat sudut kemiringan untuk membuat posisi matras menjadi miring serta instrumen yang dibutuhkan untuk mengobservasi tindakan.

3. Menyiapkan siswa untuk pembelajaran

\section{b. Tindakan}

1. Siswa dijelaskan terlebih dahulu tentang roll belakang setelah itu siswa diberi cuntoh gerakan roll belakang yang benar siswa disuruh mencoba terlebih dahulu. 
2. Siswa melakukan gerak dasar roll belakang dengan mengunakan papan yang berbentuk segitiga untuk membuat sudut kemiringan untuk membuat posisi matras menjadi miring, ini memudahkan siswa untuk belajar menjatuhkan badan sehingga siswa tanpa kesulitan melakukan secara berulang-ulang gerak dasar roll belakng.

3. Setiap siswa melakukan gerakan secara bergantian.

c. Observasi

1. Setelah tindakan dilakukan, diamati dan dikoreksi dan berikan waktu pengulangan kemudian dinilai atau dievaluasi

\section{d. Refleksi}

1. Dari data hasil observasi disimpulkan dan didiskusikan

2. Didiskusikan rencana tindakan pada siklus kedua

\section{Siklus kedua}

a. Rencana

1. Menyiapkan siswa untuk mengikuti pembelajaran penjaskes roll belakang.

2. Menyiapkan alat berupa matras dan yang berkaitan dengan proses pembelajaran dan instrumen yang dibutuhkan untuk mengobservasi tindakan.

3. Menyiapkan instrument yang diperlukan untuk mengevaluasi dan mengobservasi tindakan.

\section{b. Tindakan}

1. Siswa dibariskan dan diperintahkan mencari pasangan untuk melakukan roll belakang.

2. Siswa melakukan gerak dasar roll belakang secara berpasangan, satu siawa melakukan roll belakang dan siswa satunya membantu temannya melakukan rol belakang, terus bergantian dan berulang ulang.

3. Siswa diberikan kesempatan melakukan pengulangan pelaksanaan roll belakang.

4. Siswa melakukan roll belakang dengan benar.

\section{c. Observasi}

1. Setelah tindakan dilakukan, diamati dan dikoreksi diberikan waktu pengulangan dan dinilai maka dapat diketahui presentase keberhasilan sehingga dapat disimpulkan.

\section{d. Refleksi}

1. Kesimpulan dari hasil pembelajaran penjaskes roll belakang dan didiskusikan berapa persen peningkatan yang dicapai oleh siswa

\section{HASIL DAN PEMBAHASAN}

Sebelum penelitian ini dilaksanakan, langkah pertama yang harus dilakukan adalah melakukan tes awal. Tes awal merupakan sebuah tes yang dilakukan tanpa adanya tindakan, pada tes ini para siswa langsung di tes menggunakan instrumen yang telah dipersiapkan. Tes ini berguna untuk mengetahui tindakan yang harus dilakukan pada setiap siklus, selain itu juga berguna untuk mengetahui peningkatan hasil belajar setelah dilaksanakan pembelajaran pada siklus-siklus selanjutnya. Berikut ini adalah hasil penilaian pada tes awal:

Tabel 1. Rekapitulasi Analisis Hasil Tes Awal Pembelajaran Gerak Dasar Roll Belakang

\begin{tabular}{llcc}
\hline No & \multicolumn{1}{c}{ Hasil } & Jumlah & Persentase \\
\hline 1 & Tuntas & 4 & $23,52 \%$ \\
2 & Belum tuntas & 13 & $76,48 \%$ \\
\hline
\end{tabular}

Indikator peningkatan dapat dilihat melalui rumus:

$P=\frac{f}{n} \times 100 \%$

Persentase ketuntasan belajar:

$P=\frac{4}{17} X 100 \%=23.52 \%$

Setelah mengetahui hasil dari tes awal maka peneliti mempersiapkan tindakan pada siklus pertama. Pada siklus pertama peneliti memberikan materi gerak dasar roll belakang dengan belajar perbagian, setelah materi 
diberikan kemudian siswa di tes menggunakan instrumen penelitian, hasil dari tes pada siklus pertama adalah sebagai berikut:

Tabel 1. Rekapitulasi Analisis Hasil Pembelajaran Gerak Dasar Roll Belakang Siklus I

\begin{tabular}{llcc}
\hline No & \multicolumn{1}{c}{ Hasil } & Jumlah & Persentase \\
\hline 1 & Tuntas & 9 & $52,94 \%$ \\
\hline 2 & Belum tuntas & 8 & $47,06 \%$ \\
\hline
\end{tabular}

Indikator peningkatan dapat dilihat melalui rumus:

$P=\frac{f}{n} \times 100 \%$

Persentase ketuntasan belajar:

$P=\frac{4}{17} X 100 \%=52.94 \% \%$

Setelah mengetahui hasil tindakan dari siklus pertama belum mencapai target yang diinginkan maka peneliti melanjutkan tindakan pada siklus kedua. Pada siklus kedua peneliti memberikan materi gerak dasar roll belakang menggunakan bantuan guru, setelah materi diberikan kemudian siswa di tes menggunakan instrumen penelitian, hasil dari tes pada siklus ke dua adalah sebagai berikut:

Tabel 2. Rekapitulasi Analisis Hasil Pembelajaran Gerak Dasar Roll Belakang Siklus II

\begin{tabular}{llcc}
\hline No & \multicolumn{1}{c}{ Hasil } & Jumlah & Persentase \\
\hline 1 & Tuntas & 14 & $82,35 \%$ \\
2 & Belum tuntas & 3 & $17,65 \%$ \\
\hline
\end{tabular}

Indikator peningkatan dapat dilihat melalui rumus:

$P=\frac{f}{n} \times 100 \%$

Persentase ketuntasan belajar:

$\boldsymbol{P}=\frac{\mathbf{1 4}}{\mathbf{1 7}} \boldsymbol{X 1 0 0} \%=82.35 \%$

Setelah tindakan pada siklus ke dua selesai dan telah mencapai target yang diinginkan maka peneliti menghitung jumlah siswa yang lulus serta persentase peningkatan nilai siswa dan persentase kelulusan.

Setelah semua data dari hasil pelaksanaan tindakan telah diketahui, maka peneliti membuat rekapitulasi data pembelajaran gerak dasar roll belakang pada setiap siklus, adapun data yang diperoleh dapat dilihat pada tabel tabulasi berikut :

Tabel 3. Deskripsi Hasil Penelitian Tindakan Kelas (PTK) Pembelajaran Gerak Dasar Roll Belakang.

\begin{tabular}{|c|c|c|c|c|c|c|c|c|c|c|c|c|c|}
\hline \multirow[t]{3}{*}{ Siklus } & \multirow{3}{*}{ 之 } & \multirow{3}{*}{ 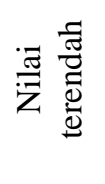 } & \multirow{3}{*}{$\bar{X}$} & \multicolumn{5}{|c|}{ Berdasarkan Rata-Rata Kelas } & \multicolumn{5}{|c|}{ Ketuntasan Belajar } \\
\hline & & & & \multicolumn{2}{|c|}{$\geq \mathrm{RK}$} & \multicolumn{2}{|c|}{$<\mathrm{RK}$} & \multirow{2}{*}{$\underset{\%}{\text { Jumlah }}$} & \multicolumn{2}{|c|}{$\geq \mathrm{KB}$} & \multicolumn{2}{|c|}{$<\mathrm{KB}$} & \multirow{2}{*}{$\underset{\%}{\text { Jumlah }}$} \\
\hline & & & & $\mathrm{f}$ & $\%$ & $\mathrm{f}$ & $\%$ & & $\mathrm{f}$ & $\%$ & $\mathrm{f}$ & $\%$ & \\
\hline $\begin{array}{c}\text { Tes } \\
\text { awal }\end{array}$ & 77,78 & 51,85 & 60,34 & 7 & 41,17 & 10 & 58,83 & 100 & 4 & 23,52 & 13 & 76,48 & 100 \\
\hline Satu & 81,48 & 55,55 & 66,22 & 9 & 52,94 & 8 & 47,06 & 100 & 9 & 52,94 & 8 & 47,06 & 100 \\
\hline Dua & 85,18 & 59,25 & 71,02 & 6 & 35,29 & 11 & 64,71 & 100 & 13 & 82,35 & 4 & 17,65 & 100 \\
\hline
\end{tabular}


Berdasarkan hasil penelitian yang di laksanakan, peneliti memperoleh data-data yang berkaitan dengan keterampilan gerak dasar roll belakang. Adapun data-data yang diperoleh adalah sebagai berikut. Dari hasil pembelajaran gerak dasar roll belakang pada siklus pertama yang dengan pembelajaran perbagian, diketahui bahwa terjadi peningkatan hasil belajar gerak dasar roll belakang dari tes awal ke siklus pertama namun peningkatan yang diperoleh pada siklus pertama belum mencapai target ketuntasan, hal ini disebabkan pada siklus pertama para siswa baru memperoleh stimulan pembelajaran sehingga peningkatan hasil belajar belum optimal. Melihat hasil belajar yang dicapai belum optimal maka peneliti merencanakan tindakan pada siklus kedua.

Setelah diberikan tindakan pada silkus kedua dengan mempergunakan bantuan guru, terjadi peningkatan hasil belajar gerak dasar roll belakang dari siklus pertama. Hasil yang diperoleh pada siklus kedua diketahui bahwa hasil belajar yang diperoleh para siswa meningkat dan telah mencapai target yang diinginkan. Pencapaian target hasil belajar yang diperoleh para siswa disebabkan karena pemberian setimulan pada setiap siklus yang optimal sehingga para siswa dapat menguasai gerak dasar roll belakang dengan baik

\section{SIMPULAN}

Berdasarkan hasil penelitian yang di lakukan, peneliti memperoleh data-data yang berkaitan dengan keterampilan gerak dasar roll belakang, adapun data-data yang diperoleh adalah sebagai berikut; Dari hasil pembelajaran gerak dasar roll belakang pada siklus pertama yang dengan pembelajaran perbagian, diketahui bahwa terjadi peningkatan hasil belajar gerak dasar roll belakang dari tes awal ke siklus pertama namun peningkatan yang diperoleh pada siklus pertama belum mencapai target ketuntasan, hal ini disebabkan pada siklus pertama para siswa baru memperoleh stimulan pembelajaran sehingga peningkatan hasil belajar belum optimal. Melihat hasil belajar yang dicapai belum optimal maka peneliti merencanakan tindakan pada siklus kedua.

Setelah diberikan tindakan pada siklus kedua dengan mempergunakan bantuan guru, terjadi peningkatan hasil belajar gerak dasar roll belakang dari siklus pertama. Hasil yang diperoleh pada siklus kedua diketahui bahwa hasil belajar yang diperoleh para siswa meningkat dan telah mencapai target yang diinginkan. Pencapaian target hasil belajar yang diperoleh para siswa disebabkan karena pemberian setimulan pada setiap siklus yang optimal sehingga para siswa dapat menguasai gerak dasar roll belakang dengan baik. Berdasarkan hasil penelitian, maka simpulan dari penelitian ini adalah:

1. Dengan penggunaan pembelajaran perbagian gerak dasar roll belakang pada siklus pertama dapat memperbaiki dan meningkatkan gerak dasar roll belakang pada siswa

2. Dengan penggunaan dengan bantuan Guru pada siklus kedua dapat memperbaiki dan meningkatkan gerak dasar roll belakang pada siswa

\section{DAFTAR PUSTAKA}

Arikunto, Suharsimi. (2010). Prosedur Penelitian Suatu Pendekatan Praktik. Jakarta: PT. Rineka Cipta.

Gumantan, Aditya dan Mahfud, Imam. (2018). Perbandingan Latihan Dengan Menggunakan Bola Ukuran 4 dan 5 Terhadap Ketepatan Menendang Bola ke Arah Gawang. Journal of S.P.O.R.T, 2 (1), 1 - 7.

Hidayat, Imam. (1996). Senam. Bandung: FPOK UPI.

Hurlock, Elizabeth. (1998). Perkembangan Anak. Jakarta: Erlangga.

Lutan, Rusli. (1998). Perencanaan dan Strategi Pembelajaran Penjaskes. Jakarta: Depdikbud.

Mahendra, Agus. (2004). Teori dan Metode Pembelajaran Senam. Bandung: FPOK UPI.

Mahfud, Imam. Fahrizqi, Eko Bagus (2020). Pengembangan Model Latihan Keterampilan Motorik Melalui Olahraga Tradisional. Untuk Siswa Sekolah Dasar. Sport Science and Education Journal. 1 (1), 31-37.

Muhajir. (2006). Pendidikan Jasmani Olah Raga dan Kesehatan. Jakarta: Erlangga.

Mulyana, Fegie R. (2018). Hubungan Fleksibilitas Panggul dan Power Otot Lengan Dengan Keterampilan Stut Pada Senam Lantai. Journal of S.P.O.R.T, 2(1), 43-48.

Mulyaningsih, Farida, dkk. (2010). Pendidikan Jasmani Olahraga dan Kesehatan Untuk SD/MI kelas V. Jakarta: Kementerian Pendidikan Nasional.

Yuliandra, Rizki. Fahrizqi, Eko Bagus. (2019). Pengembangan Model Latihan Jump Shoot Bola Basket. Journal of S.P.O.R.T, 3(1), 51-55. 


\section{BIOGRAFI PENULIS}

Farhan Ramadhani Pangkey
Lahir di Bandar Lampung, 24 Desember 1998, saat ini sedang menempuh
Pendidikan Sarjana (Strata-1) di Universitas Teknokrat Indonesia dengan
mengambil Program Studi Pendidikan Olahraga angkatan 2017. Penulis Aktif
sebagai pemain di UKM Basket Universitas Teknokrat Indonesia. Penulis juga
merupakan Asisten Dosen di Program Studi. Penulis dapat dihubungi melalui Email
:arhanramadhanipangkey04@gmail.com

